Volume 11, Nomor 1, Mei 2019, pp 77 - 97 Copyright (C) 2017 Jurnal Akuntansi Maranatha, Program Studi Akuntansi, Fakultas Ekonomi,Universitas Kristen Maranatha. ISSN 2085-8698 | e-ISSN 2598-4977. http://journal.maranatha.edu

\title{
Analisa Karakteristik Peminum Teh di Kota Bandung
}

\author{
Fernando Leonardo \\ Program Studi Magister Manajemen-Universitas Katolik Parahyangan \\ fernando.sijabat@gmail.com \\ Nur Imam Taufik \\ STIA - Lembaga Administrasi Negara Bandung \\ nurimamtaufik@gmail.com \\ Dwi Rianawati \\ Program Studi Magister Manajemen-Universitas Katolik Parahyangan \\ dwirianawati@gmail.com
}

\begin{abstract}
The surplus of tea industries in Indonesia is predicted to reach 56.877 tons in 2020. The decrease in the value of exports and the increase of tea production with a low tea consumption level has been the cause of this phenomenon. One of the ways to prevent this from happening is by improving tea consumption level in Indonesia. This studyaims to determine the characteristics of tea drinkers in the city of Bandung which is one of the major cities in Indonesia. This study uses a descriptive method with a qualitative approach. The number of sample used was 350 tea drinkers in Bandung who were processed using cross tabulation analysis techniques. The results showed that tea drinkers in Bandung were consumers who were in the middle to upper category who were practical people who liked tea in a package with a fresh tea flavor but not too bitter, and refreshing.
\end{abstract}

Keywords: Tea, Targeting, Consumers' Characteristics

\section{Pendahuluan}

Teh merupakan salah satu minuman yang cukup favorit di Indonesia (Meriza et al, 2016).Kebiasaan minum teh di Indonesia tersebar di seluruh wilayah Indonesia. Mereka mengkonsumsi teh sesuai dengan kesukaan mereka masing-masing, seperti es teh, teh panas, teh manis, teh tawar, dll. Jenis teh yang dikonsumsi pun tergantung pada kesukaan mereka seperti teh hijau, teh hitam, teh putih, dan teh oolong.Teh dipercaya memberikan banyak manfaat bagi kesehatan seperti mencegah berat badan berlebih, anti aging, mencegah stress dan cemas, anti kanker, dll. Setiap jenis teh mempunyai manfaat yang berbeda-beda, untuk memperoleh manfaat secara maksimal maka disarankan untuk 
mengkonsumsi teh sesuai dengan kebutuhannya (Towaha et al, 2012).

Industri teh pada saat ini sedang menghadapi berbagai masalah, salah satunya adalah turunnya nilai ekspor teh.Selama ini Indonesia selalu ketergantungan terhadap penjualan ekspor teh.Pada tahun 1980 volume ekspor teh sebesar 75 ribu ton dan turun menjadi 62 ribu ton pada tahun 2015. Disisi lain perkembangan volume impor teh tahun 1980-2015 cenderung naik dengan ratarata pertumbuhan sebesar $99,77 \%$ per tahun. Tahun 1980 Indonesia impor teh sebesar 51 ton dan pada tahun 2015 volume impornya menjadi 15 ribu ton (Gambar 1). Produksi teh di Indonesia mengalami peningkatan, pada tahun 1980 total sebesar 106 ribu ton dan pada tahun 2015 naik hingga hampir mencapai 155 ribu ton. Hal tersebut diatas mengakibatkan Indonesia diproyeksikan mengalami surplus teh, pada tahun 2016 surplus teh Indonesia diproyeksikan sebesar 36.658 ton.Surplus teh diproyeksikan terus meningkat hingga mencapai 56.877 ton pada tahun 2020 (Sekretariat Jenderal Kementerian Pertanian, 2016).

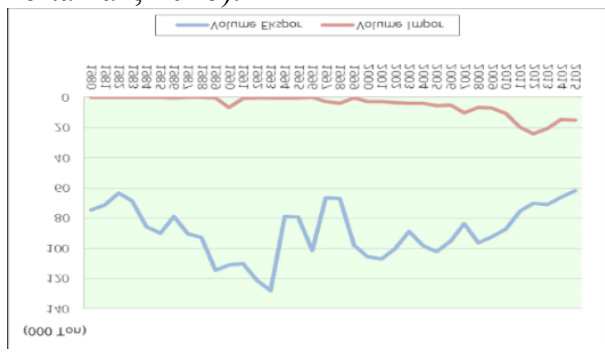

Gambar 1

\section{Perkembangan Volume Ekspor dan Impor Teh di Indonesia Tahun1980- 2015}

Di sisi lain konsumsi teh masyarakat Indonesia yang masih tergolong rendah yaitu pada tahun 2015 konsumsinya 0,18 $\mathrm{kg} / \mathrm{kap} / \mathrm{thn}$, mengalami penurunan dibandingkan konsumsi teh tahun 2002 sebesar $0,77 \mathrm{~kg} / \mathrm{kap} / \mathrm{thn}$. Konsumsi teh tertinggi dicapai pada Tahun 2007 yaitu sebesar $0,78 \mathrm{~kg} / \mathrm{kap} / \mathrm{thn}($ Gambar 2)

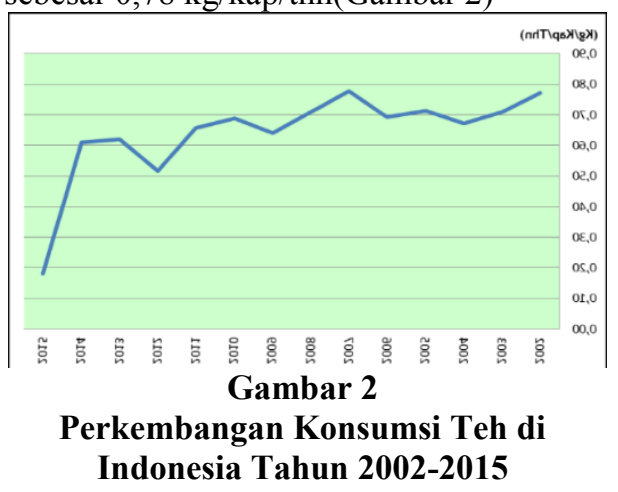

Salah satu upaya untuk mengatasi surplus teh di Indonesia dengan cara meningkatkan konsumsi teh dalam negeri, populasi di Indonesia pada 30 Juni 2016 adalah 257.912.349 (Setiawan, 2016). Potensi dalam negeri apabila dilihat dari jumlah populasi penduduk di Indonesia maka akan terlihat cukup besar. Memahami perilaku konsumen teh merupakan informasi pasar yang sangat penting bagi sektor agribisnis teh.Informasi ini sangat diperlukan sebagai bahan masukan untuk merencanakan dan mengembangkan produk dan memasarkannya dengan baik. Dengan memenuhi dan memuaskan kebutuhan dan keinginan konsumen akan permintaan komoditi yang mereka usahakan, maka masalah kegagalan pasar atau anjloknya harga dapat diminimalisir. Oleh sebab itu perlu untuk mengetahui faktor-faktor yang dapat mempengaruhi perilaku konsumen untuk membeli suatu produk (Kotler \& Keller, 2009).

Bandung adalah salah satu kota besar di Indonesia dengan jumlah penduduk 2.490.622 jiwa pada tahun 2016 (BPS, 2017). Jumlah penduduk kota Bandung tidak mencangkup $1 \%$ dari jumlah penduduk di Indonesia, tetapi penelitian dilakukan di Bandung salah satu alasannya karena Bandung tidak hanya terkenal dari sisi pariwisatanya namun juga dari kekayaan sajian kuliner khas 
daerahnya (Dehotman, 2018), sehingga Bandung menjadi kiblat kuliner di Indonesia. Diharapkan dengan mengetahui perilaku konsumen peminum teh di Bandung, para pemasar teh dapat meningkatkan tingkat konsumsi untuk tahap pertama di kota Bandung sendiri kemudian dapat menular ke seluruh Indonesia.

Berdasarkan uraian tersebut maka penting mengetahui tentang perilaku konsumen para peminum teh untuk mendapatkan karakteristik konsumen peminum teh dari berbagai macam jenis teh (teh hitam, teh oolong, teh hijau dan teh putih). Mengetahui karakteristik konsumen menjadi sangat penting, karena dinilai dapat membuat pemasar menghemat biaya untuk promosi, hal ini terkait dengan para pemasartelah mengetahui siapa konsumen potensial mereka.Setelah itu maka para pemasar teh dapat menganalisa strategi pemasaran yang paling tepat berdasarkan karakteristik konsumen, yang dapat diterapkan oleh para pemasar teh di Indonesia. Hal ini sangat penting mengingat bahwa Indonesia harus terus berusaha untuk meningkatkan konsumsi dalam negeri sebagai salah satu cara untuk mengatasi surplus teh yang diproyeksikan terus mengalami peningkatan sampai tahun 2020 mencapai sebesar 56.877 ton.(Sekretariat Jenderal Kementerian Pertanian, 2016).

\section{Kerangka Teoritis}

Pada saat sekarang ini industri agrobisnis teh di Indonesia sedang mengalami masalah menurunnya nilai ekspor yang mengakibatkan Indonesia di proyeksikan mengalami surplus teh sampai dengan 56.877 ton pada tahun 2020 (Sekretariat Jenderal Kementerian Pertanian, 2016). Salah satu cara untuk mengatasi surplus teh yang terjadi di Indonesia adalah dengan cara meningkatkan konsumsi teh di dalam negeri. Konsumsi teh di
Indonesia pada tahun 2016 hanya 350gr/perkapita/pertahun, apabila di Indonesia konsumsi teh mencapai 500gr/perkapita/tahun maka hasil produksi teh dapat terserap di dalam negeri tanpa harus melakukan ekspor teh (Novalius, 2016).

Agar konsumsi teh di Indonesia dapat ditingkatkan maka perlu untuk mengetahui karakteristik konsumen dari para peminum teh menurut jenis teh dan apa yang diinginkan oleh masyarat terhadap produk teh yang beredar di pasar teh Indonesia. Dalam cara meningkatkan penjualan suatu produk diperlukan strategi pemasaran yang tepat sasaran. Dalam melakukan strategi pemasaran para pengusaha harus memahami terlebih dahulu konsumennya, maksudnya adalah bahwa pengusaha harus bisa mengetahui apa yang dibutuhkan dan diinginkan oleh si konsumen atau perilaku konsumen tersebut karena untuk melakukan strategi pemasaran diperlukan pengetahuan tentang perilaku konsumen (Putri et al, 2014). Perilaku konsumen adalah studi bagaimana individu, kelompok dan organisasi memilih, membeli, menggunakan dan menempatkan barang, jasa, ide atau pengalaman untuk memuaskan keinginan dan kebutuhan mereka (Kotler \& Keller, 2009). Karakteristik peminum teh akan ditentukan oleh faktor - faktor yang mempengaruhi keputusan pembelian teh berdasarkan dari jenis teh yang para responden nikmati, faktor tersebut antara lain faktor sosial, faktor kebudayaan dan faktor pribadi (Kotler \& Keller, 2009).

Preferensi konsumen adalah sikap pelanggan yang menginginkan suatu barang atau jasa berdasarkan kemampuan yang dimiliki untuk memberikan nilai kepuasan terhadap apa yang dibeli atau yang ditawarkan, sehingga orang yang menginginkan barang atau jasa telah mempunyai sikap perilaku pembelian (Marwan, 1990). Perbedaan preferensi dari masing - masing konsumen inilah 
yang menyebabkan karakteristik dari setiap konsumen jenis teh menjadi berbeda - beda. Preferensi konsumen ini juga ditentukan oleh faktor - faktor yang mempengaruhi keputusan pembelian yang dikemukan oleh (Kotler \& Keller, 2009).

Setelah mengetahui karakteristik dari para meminum teh maka dapat dianalisa bagaimana strategi pemasaran yang paling tepat di Indonesia guna untuk meningkatkan konsumsi teh.Menentukan strategi pemasaran yang tepat, selain dengan mengetahui perilaku konsumen harus dengan mempertimbangkan persaingan bisnis yang muncul sesuai dengan perkembangan jaman yang ada.Dengan menggunakan konsep dan strategi pemasaran dalam menjalankan kegiatan bisnis, diharapkan perusahaan dapat menghadapi persaingan sekaligus dapat meraih keberhasilan bisnis bagi perusahaan bersangkutan (Pasigai, 2009). Dalam menentukan strategi pemasaran teh di Indonesia maka perlu juga mempertimbangkan persaingan bisnis yang muncul agar strategi pemasaran yang ditetapkan dapat untuk menghadapi persaingan bisnis dimasa sekarang dan yang akan datang.

\section{Strategi Pemasaran}

Untuk dapat memasarkan suatu produk atau jasa, suatu perusahaan membutuhkan strategi pemasaran yang tepat.Strategi pemasaran merupakan suatu pola pikir pemasaran yang nantinya akan dipergunakan untuk menggapai tujuan pemasaran dan berisi strategi rinci untuk pasar sasaran, penetapan posisi, bauran pemasaran dan besaranya pengeluaran pemasaran (Kotler \& Keller, 2009).

Menurut (Kotler \& Keller, 2009) strategi pemasaran dapat terbagi menjadi 3 bagian, yaitu:

\section{Segmentasi (Segmentation)} didefinisikan sebagai sekelompok pelanggan yang memiliki himpunan keinginan yang sama, dan hal tersebut merupakan tugas pemasar untuk mengidentisifikasi segmen-segmen tersebut. Proses untuk melakukan segmentasi dilakukan dengan memecah-mecah pasar yakni dengan meneliti hirarki dari atribut-atribut yang mempengaruhi pelanggan dalam memilih suatu merk tertentu. Untuk melakukan dengan cara efektif maka segmen pasar harus bersifat terukur (measurable), penting (substansial), dapat dimasukan (accessible), dapat dibedakan (differentiable), dan dapat ditindaklajuti (actionable).Segmentasi sendiri terdiri dari 4 kriteria, yaitu segmentasi geografis, segmentasi demografis, segmentasi psikografis, segmentasi perilaku.

2. Sasaran pasar (targeting)adalah proses mengevaluasi daya tarik setiap segmen pasar dan memilih satu atau beberapa segmen pasar untuk dimasuki. Adapun lima pola pemilihan segmentasi yaitu kosentrasi pada satu segmen (single-segment concentration), spesialisasi selektif (selective specialization), spesialisasi produk (product specialization), spesialisasi pasar (market specialization) dan pencangkupan seluruh pasar (full market corverage). Targetting merupakan penetapan segmen pasar yang akan dijadikan target utama perusahaan dalam kegiatan akhir dari pemasaran yaitu penjualan, keuntungan, biaya penjualan, mudah dijangkau dan berpotensi untuk tumbuh.

3. Penetapan posisi pasar (positioning)merupakan pengaturan agar suatu produk menduduki tempat yang jelas, berbeda dan dikehendaki relatif berbeda terhadap produk pesaing dipemikiran konsumen sasaran. Penetapan posisi pasar merupakan alasan keberadaan suatu produk dengan kata lainpositioning adalah janji perusahaan terhadap pelanggan. Dalam penetapan posisi pasar harus memperhatikan 4 kriteria, 
yaitu: berdasarkan pelanggan, berdasarkan kemampuan internal perusahaan, berdasarkan pesaing perusahaan, dan berdasarkan perubahan lingkungan bisnis.Positioning juga merupakan bagaimana perusahaan mempengaruhi pelanggan, mendesain pesan-pesan pemasaran sehingga sebuah produk yang ditawarkan dianggap unik dan bernilai oleh pelanggan. Strategi untuk pelanggan merupakan kombinasi dari strategi produk, jaringan pemasaran, harga dan promosi yang membutuhkan diferensiasi.

Menurut (Whalley, 2010) proses segmentation, targeting dan positioning (STP) merupakan jantung dari konsep pemasaran. Manusia memiliki karakteristik yang berbeda-beda, orangorang tertentu akan lebih tertarik dengan produk atau jasa yang ditawarkan oleh sebuah perusahaan dibanding yang lain.

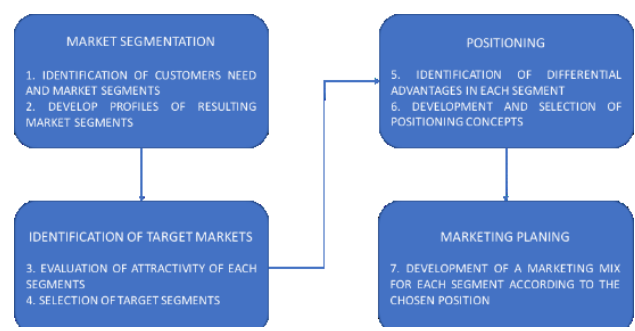

Gambar 4

Proses STP

Proses dalam STP yang harus dilakukan adalah mengenali dasar-dasar untuk melakukan segmentasi pasar, mengembangkan variabel untuk melakukan segmentasi pasar seperti demografis, geografis, psikografis dan behavior.Mengenali profil target pasar serta memilih target pasar dari hasil segmentasi pasar.Melakukan positioning dimana perusahaan merancang penawaran yang mengarah ke segmen pasar tertentu dan menempati tempat tertentu didalam pikiran segmen pasar, kemudian mengembangkan dan mengkomunikasikan positioning produk atau jasa untuk segmen pasar.Menurut (Whalley, 2010) secara umum ada tiga pendekatan strategi dalam pemasaran yang berhubungan dengan STP proses, yaitu:

1. Undifferentiated strategy:Pada strategi ini semua konsumen diperlakukan setara atau sama dan perusahaan tidak melakukan usaha khusus untuk memuaskan kelompok tertentu. Strategi ini biasanya hanya berfungsi pada komoditas dimana produknya standard dan pesaing juga tidak bisa menawarkan hal lebih. Dalam hal ini tidak dibutuhkan segmentasi.

2. Concentrated strategy: Pada strategi ini perusahaan memilih untuk fokus pada satu segment dan membiarkan segment lain untuk diambil pesaing. Sehingga penguna strategi ini hanya butuh memahami satu segment khusus dan bukan keseluruhan pasar.

3. Differentiated strategy: Strategi ini merupakan kebalikan dari Concentrated strategy. Strategi ini menjangkau beberapa segmen sehingga perusahaan butuh memahami keseluruhan pasar dan membaginya berdasarkan kebutuhan.

\section{Perilaku Konsumen}

Beberapa pengertian perilaku konsumen menurut beberapa ahli:

1. Kotler dan Keller: "studi bagaimana individu, kelompok dan organisasi memilih, membeli, menggunakan dan menempatkan barang, jasa, ide atau pengalaman untuk memuaskan keinginan dan kebutuhan mereka" (Kotler \& Keller, 2009).

2. Solomon: "Consumer behavior is the study of the processes involved when individuals or groups select, purchase, use, and dispose of goods, services, ideas, or experiences to satisfy their needs and desires" (Solomon, 2011). 
3. Perilaku konsumen didefinisikan sebagai perilaku menggunakan, mengevaluasi, dan menghabiskan produk dan jasa yang mereka harapkan akan memuaskan kebutuhan mereka (Schiffman \& Kanuk, 2010).

Perilaku konsumen dipengaruhi oleh beberapa faktor yaitu (Kotler \& Keller, 2009):

a. Faktor Budaya

Budaya adalah faktor penentu dominan dari keinginan serta perilaku seseorang (Kotler \& Keller, 2009).Budaya adalah penentu dasar seseorang dalam menentukan keinginan serta tingkah lakunya (Schiffman \& Kanuk, 2010). Setiap budaya terdiri dari sub budaya yang menyediakan identifikasi yang spesifik dan sosialisasi dari setiap anggotanya. Sub budaya termasuk nasionalitas, agama, ras dan area geografi. Konsumen sebagai manusia pada hakikatnya menunjukkan stratifikasi sosial yang berbentuk kelas sosial.Contohnya terbagi atas kelas bawah, menengah dan atas. Karakteristik kelas sosial terdiri dari:

- Setiap kelas sosial cenderung lebih sama dalam berpakaian, pola bicara dan preferensi rekreasi.

- Orang diterima sebagai posisi inferior atau superior menurut kelas sosial.

- Kelompok variabel, contohnya pekerjaan, pendapatan, kesejahteraan, pendidikan dan orientasi nilai.

- Individu dapat naik ataupun turun kelas sosial selama hidupnya.

b. Faktor Sosial

Faktor sosial seperti kelompok referensi, keluarga dan peran dan status sosial mempengaruhi perilaku pembelian. Kelompok referensi dapat dibedakan atas dua kelompok, yaitu:
(1) kelompok primer : yaitu kelompok yang berinteraksi terus menerus dan informal, contohnya keluarga, teman, tetangga dan teman kerja.

(2) kelompok kedua : yaitu kelompok yang tidak berinteraksi terus menerus dan cenderung lebih formal, contohnya kelompok agama, profesi, persatuan usaha.

Kelompok referensi memberikan pengaruh dengan tiga cara yakni melalui perilaku dan gaya hidup baru, mempengaruhi sikap dan konsep diri, serta menciptakan tekanan untuk kesesuaian yang mempengaruhi pemilihan produk dan brand.

c. Faktor Personal

Dalam faktor personal, keputusan pembeli dipengaruhi oleh karakteristik pribadi. Termasuk disini adalah umur dan tahap dalam siklus hidup, pekerjaan dan lingkungan ekonomi, kepribadian dan konsep diri, gaya hidup dan nilai-nilai.

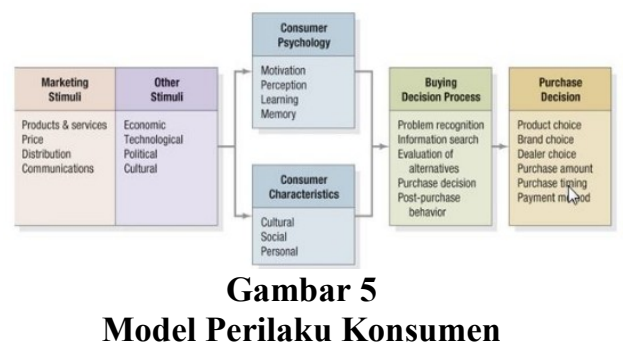

\section{Karakteristik Konsumen}

Suatu perusahaan untuk memasarkan produknya harus memahami apa yang terjadi dalam diri pembeli. Salah satu komponen utama dari diri pembeli adalah karakteristik konsumen (Kotler \& Keller, 2009).Pengetahuan tentang karakteristik konsumen yang tidak mencukupi membatasi nilai produk yang ditawarkan perusahaan kepada konsumen tersebut.Dengan mengetahui karakteristik 
konsumen, perusahaan dapat berinvestasi secara tepat pada konsumen yang berharga dan mengurangi biaya yang dikeluarkan untuk konsumen yang kurang berpotensi.Mengetahui karakteristik konsumen adalah salah satu strategi yang paling populer untuk mengetahui lebih banyak tentang pelanggan. Karakteristik konsumen adalah suatu teknik yang mengubah informasi mentah tentang pelanggan menjadi pengetahuan pendukung strategis yang memperkuat nilai barang yang ditawarkan perusahaan kepada pelanggan $(\mathrm{Wu}$ et al, 2009).Metode yang paling sering digunakan untuk menentukan karakteristik konsumen adalah segmentasi, yaitu segmentasi demografis yang meliputi usia, jenis kelamin, jumlah anggota keluarga, jumlah orang, keluarga status perkawinan, agama, pendapatan, pekerjaan, pendidikan dan ras (Kotler \& Keller, 2009).

\section{Preferensi konsumen}

Preferensi konsumen adalah sikap pelanggan yang menginginkan suatu barang atau jasa berdasarkan kemampuan yang dimiliki untuk memberikan nilai kepuasan terhadap apa yang dibeli atau yang ditawarkan, sehingga orang yang menginginkan barang atau jasa telah mempunyai sikap perilaku pembelian (Marwan, 1990). Pemahaman preferensi konsumen bertujuan untuk meneruskan strategi pemasaran yang secara berkelanjutan agar barang atau jasa yang dijual atau dipasarkan tetap diminati oleh konsumen.Preferensi konsumen sebagai interaksi dinamis antara pengaruh dan kognisi, perilaku dan kejadian disekitar kita dimana manusia melakukan aspek pertukaran dalam hidup mereka.Dari definisi tersebut dapat diketahui tiga ide penting, pertama preferensi pelanggan adalah dinamis, kedua, bahwa hal tersebut melibatkan interaksi antara pengaruh dan kognisi, perilaku dan kejadian di sekitar, dan ketiga bahwa hal tersebut melibatkan pertukaran.
Mempelajari preferensi konsumen adalah sangat kompleks, yang dikarenakan banyaknya karakteristik yang mempengaruhi dan kecenderungan untuk saling berinteraksi. Howard dan Sheth mengemukakan preferensi pelanggan dalam suatu gambaran proses pengambilan keputusan membeli. Preferensi konsumen terdiri atas empat komponen pokok yakni masukan (stimuli), susunan hipotesis (susunan persepsi melalui proses belajar), hasil tanggapan atau keputusan membeli dan karakteristik-karakteristik eksogen (Sheth et al, 1998).

Masukan merupakan stimuli atau dorongan yang dirasakan oleh pelanggan, dan dorongan dapat bersifat komersial dan sosial. Dorongan komersial berasal dari rumah tangga produksi (perusahaan) yang terdiri dari dorongan signifikatif yang bersumber dari paduan komponen produk, penjualan dan distribusi, dorongan simbolik yang bersumber dari paduan komponen promosi, dan dorongan sosial berasal dari rumah tangga konsumsi yang timbul atas dasar komunikasi antar anggota dalam satu kelompok dan dengan kelompok yang berbeda.Selanjutnya keputusan membeli merupakan suatu hasil, kecenderungan pelanggan untuk membeli produk atau jasa yang paling disukai adalah sesuai dengan tujuan, yakni memperoleh kepuasan dalam pembelian (Reyner, 2017).

\section{Teh}

Teh putih, hijau, oolong dan hitam sebenarnya berasal dari satu tanaman, yaitu Camellia sinesis. Yang berbeda adalah masa pengambilan daun teh yang disesuaikan dengan jenis teh yang diinginkan dan cara pengolahan daun teh tersebut. Teh yang berasal dari tanaman teh dibagi menjadi 4 kelompok: teh hitam, teh oolong, teh hijau, dan teh putih (Soekotjo, 2015). Jenis - jenis teh yang dipasarkan memiliki perbedaan dalam 
proses pengolahannya, yaitu (Tutut, 2017):

1. Teh hitam: Untuk menghasilkan daun teh hitam, maka daun teh yang berwarna hijau dibiarkan sampai menjadi warna coklat lewat proses oksidasi (kadang-kadang disebut sebagai fermentasi) sehingga menghasilkan warna dan rasa yang khas. Teh hitam diproses dengan cara di fermentasi kemudian dikeringkan dan dihancurkan. Teh hitam ini memiliki kafein yang lebih tinggi dibandingkan teh lainnya.

2. Teh oolong: Jenis yang satu ini berasal dari Tionghoa dan juga memiliki kafein. Rasa dari minuman ini pahit namun setelah habis meminumnya akan ada rasa manis tertinggal di lidah. Teh ini memiliki harum yang menarik dan sering dibandingkan dengan rasa dan aroma bunga segar ataupun buah segar. Teh oolong hampir sama dengan teh hitam hanya proses fermentasinya lebih sebentar.

3. Teh hijau: Teh hijau memiliki kafein rendah yang berasal dari daun tanaman camellia sinensis yang hanya dikukus, sehingga mencegah hilangnya kandungan katekin. Sedangkan teh hitam atau teh oolong dibuat dari daun yang difermentasi, sehingga menyebabkan hilangnya senyawa anti oksidan.

4. Teh putih: Seperti teh yang lainnya, teh putih juga berasal dari camellia sinensis. Merupakan jenis teh terbaik karena hanya diambil pucuknya saja dan dibiarkan layu secara alami. Teh putih adalah daun teh yang belum diawetkan dan di oksidasi. Teh putih kadang mengandung bunga dan daun teh yang masih muda yang kemudian diketahui mengandung kafein lebih rendah dibandingkan daun yang lebih tua dan dapat disimpulkan bahwa teh putih mengandung lebih sedikit kafein dibandingkan dengan teh hijau. White tea merupakan jenis teh terbaik karena hanya diambil pucuknya saja dan dibiarkan layu secara alami.

\section{Metode Penelitian}

\section{Jenis Penelitian}

Peneliti melakukan penelitian deskriptif dengan pendekatan kualitatif yaitu prosedur penelitian yang menghasilkan data deskriptif berupa kata-kata tertulis atau lisan dari orang-orang dan perilaku yang dapat diamati (Bogdan \& Taylor, 1992).Hasil dari penelitian ini dideskripsikan secara secara terstruktur dan kesimpulan diambil secara subyektif berdasarkan pengambilan modus jawaban dari hasil pengolahan data menggunakan program SPSS tabulasi silang (cross tabulation) dari jawaban kuesioner.

Metode pengumpulan data menggunakan metode survei.Tujuan metode penelitian untuk mencari informasi data penelitian dari pertanyaan dapat terungkap secara faktual dan terperinci yang menggambarkan fenomena yang ada.Selain menggunakan metode survei, penelitian ini melakukan pengumpulan data dengan interview dan study literature.

\section{Populasi dan Sampel}

Populasi dari penelitian ini adalah seluruh masyarakat kota Bandung yang pernah mengkonsumsi teh. Sampel yang digunakan dalam penelitian ini diambil dengan menggunakan pendekatan nonprobability sampling, teknik pengambilan sampel ini tidak memberikan peluang/kesempatan yang sama bagi setiap unsur atau anggota populasi unruk dipilih menjadi sampel. Non-probability sampling dengan metode purposive sampling yang berarti menentukan sampel dengan pertimbangan tertentu (Sugiyono, 2017). Penelitian ini menggunakan asumsi sampling error sebesar $10 \%$ dan interval kepercayaan 95\%, sehingga didapatkan data dari tabel z sebesar 1,96. Adapun jumlah sampel minimum yang diperoleh 
dari perhitungan adalah 97 sampel (Aaker et al, 2001). Rumus perhitungan tersebut adalah sebagai berikut:

$n=\frac{0.25 \times z^{2}}{e^{2}}$

$n=\frac{0.25 \times(1.96)^{2}}{0.1^{2}}=96.04 \approx 97$

Dimana:

$\mathrm{n}=$ ukuran sampel minimum

$\mathrm{Z}=$ nilai $\mathrm{z}$ untuk interval kepercayaan $\alpha$

$\mathrm{e}=$ tingkat kesalahan

Menurut hasil perhitungan diperoleh nilai $\mathrm{n}=96.04$ dibulatkan menjadi 97. Maka penelitian ini harus menggunakan sampel minimal sebanyak 97 responden.Pada penelitian ini diperoleh sebanyak 350 responden, maka penelitian ini sudah memenuhi syarat sampel minimal.

\section{Teknik Analisis Data}

Dalam penelitian ini hasil kuesioner yang sudah terkumpul akan dianalisis dengan menggunakan program SPSS dengan metode analisis cross tabulation. Analisis tabulasi silang (cross tabulation) dilakukan untuk melihat apakah terdapat hubungan deskriptif antara 2 variabel atau lebih dari data yang sudah diperoleh (Maholtra, 2004). Hasil dari kuesioner dalam penelitian ini yang akan dianalisis untuk mencari hubungan deskriptif adalah:

- Karakteristik umum peminum teh di Bandung.

- Karakteristik peminum teh berdasarkan jenis teh hitam, teh hijau, teh oolong dan para peminum teh yang tidak mengetahui jenis teh yang mereka konsumsi. Hal ini dilakukan untuk mengetahui lebih dalam mengenai karakteristik peminum teh.

\section{Operasionalisasi Variabel}

Tabel 1

Operasional Variabel

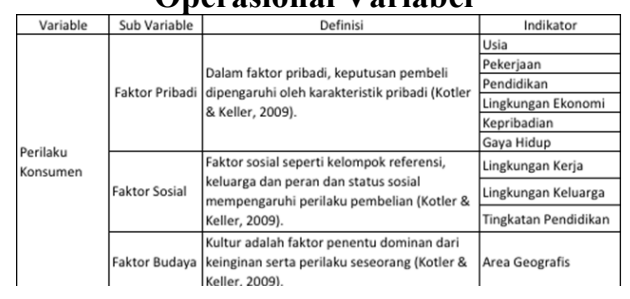

Hasil Penelitian dan Pembahasan

Pada penelitian ini kuesioner disebar menggunakan google form kepada 350 orang responden peminum teh yang ada di kota Bandung. Adapun responden adalah orang yang berada di kota Bandung dan mengkonsumsi teh. Dari hasil kuesioner yang diberikan kepada 350 responden, berdasarkan jenis kelamin 141 responden adalah pria dan 209 adalah wanita. Berdasarkan usia, 20 responden berusia $\leq 17$ tahun, 172 responden berusia antara 18 sampai dengan 30 tahun, 107 responden berusia antara 31 sampai dengan 40 tahun, 30 responden berusia antara 41 sampai dengan 50 tahun, 20 responden berusia antara 51 sampai dengan 60 tahun dan 1 respon yang berusia $\geq 60$ tahun.Berdasarkan tingkat pendidikan 7 responden lulusan SMP, 69 responden lulusan SMA, 57 responden lulusan D1/D2/D3, 180 responden lulusan $\mathrm{S} 1,35$ responden lulusan S2 dan 2 responden lulusan S3. Berdasarkan daerah asal, mayoritas responden sebanyak 232 responden adalah berasal dari Jawa Barat, 3 responden berasal dari Bali, 1 responden berasal dari Belitung, 1 responden berasal dari Flores, 14 responden berasal dari Jakarta,34 responden berasal dari Jawa Tengah, 22 responden berasal dari Jawa Timur, 1 responden berasal dari Kalimantan, 1 responden berasal dari Lampung, 6 responden berasal dari NTT, 1 responden berasal dari Palembang, 1 responden berasal dari Papua, 4 responden 
berasal dari Sulawesi, 29 responden berasal dari Sumatera. Berdasarkan pekerjaan mayoritas responden sebanyak 187 responden adalah pegawai swasta, 1 responden adalah dokter, 49 responden adalah ibu rumah tangga, 4 responden adalah pegawai BUMN, 80 responden adalah pelajar/mahasiswa, 8 responden adalah pengajar, 4 responden adalah PNS, 17 responden adalah wirausaha. Berdasarkan pengeluaran per bulan, 33 responden mengeluarkan $\leq 700.000$ perbulan, 23 responden mengeluarkan antara 700.001 sampai dengan 1.000 .000 perbulan, 30 responden mengeluarkan antara 1.000.001 sampai dengan 1.500 .000 perbulan, 46 responden mengeluarkan antara 1.500.001 sampai dengan 2.000.000 perbulan, 56 responden mengeluarkan

\section{Karakteristik Peminum Teh} Berdasarkan Jenis Teh Di Bandung

Tabel 2

Hasil Crosstab Responden

Berdasarkan Jenis Kelamin, Jenis Teh, Usia, Daerah Asal Dan Tingkat Pendidikan

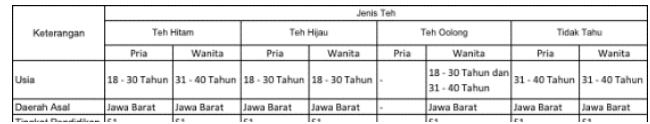

Tabel 3

Hasil Crosstab Responden Berdasarkan Jenis Kelamin, Jenis Teh, Usia, Daerah Asal Dan Pekerjaan

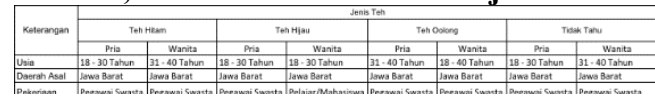

Tabel 4

Hasil Crosstab Responden

Berdasarkan Jenis Kelamin, Jenis Teh, Usia, Daerah Asal Dan Pengeluaran

Per Bulan

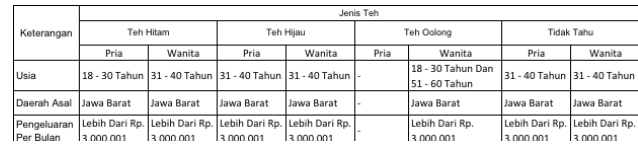

antara 2.000.001 sampai dengan 3.000.000 perbulan, dan mayoritas 162 responden mengeluarkan $\geq 3.000 .001$ perbulan, Menurut AC Nielsen masuk kedalam kategori kelas A2 yang berarti masuk ke dalam kategori kelas menengah atas (Mulyadi, 2011). Berdasarkan jenis teh, 104 responden mengkonsumsi teh hitam, 18 responden mengkonsumsi teh oolong, 1 responden mengkonsumsi teh putih, 87 responden mengkonsumsi teh tanpa mengetahui jenis teh apa yang mereka konsumsi dan mayoritas sebanyak 140 responden mengkonsumsi teh hijau. Teh hijau pada saat ini menjadi favorite dikarenakan masyarakat diperkotaan sedang tren untuk bergaya hidup sehat (Secawardaya, 2015).

\section{Tabel 5}

Responden Berdasarkan Jenis Kelamin, Jenis Teh Dan Hobby

\begin{tabular}{|c|c|c|c|c|c|c|}
\hline \multirow[b]{2}{*}{$\begin{array}{c}\text { Jenis } \\
\text { Kelamin }\end{array}$} & \multirow[b]{2}{*}{ Hobby } & \multicolumn{4}{|c|}{ Jenis Teh } & \multirow[b]{2}{*}{ Total } \\
\hline & & $\begin{array}{c}\text { Teh } \\
\text { Hitam }\end{array}$ & $\begin{array}{c}\text { Teh } \\
\text { Hijau }\end{array}$ & $\begin{array}{c}\text { Teh } \\
\text { Oolong }\end{array}$ & $\begin{array}{l}\text { Tidak } \\
\text { Tahu }\end{array}$ & \\
\hline \multirow[t]{10}{*}{ Pria } & Membaca & 16 & 16 & 2 & 7 & 41 \\
\hline & Olah Raga & 19 & 33 & 5 & 23 & 80 \\
\hline & Nonton & 21 & 23 & 1 & 17 & 62 \\
\hline & Belanja & 4 & 4 & 1 & 2 & 11 \\
\hline & Memasak & 4 & 4 & 2 & 1 & 11 \\
\hline & Menari & 1 & 0 & 0 & 0 & 1 \\
\hline & Tidur & 12 & 16 & 0 & 9 & 37 \\
\hline & Traveling & 9 & 19 & 1 & 7 & 36 \\
\hline & Menyanyi & 2 & 4 & 1 & 5 & 12 \\
\hline & Keterampilan & 4 & 2 & 0 & 1 & 7 \\
\hline \multirow[t]{11}{*}{ Wanita } & Membaca & 20 & 28 & 3 & 19 & 70 \\
\hline & Olah Raga & 15 & 22 & 4 & 10 & 51 \\
\hline & Nonton & 17 & 34 & 2 & 18 & 71 \\
\hline & Belanja & 12 & 18 & 3 & 10 & 43 \\
\hline & Memasak & 13 & 25 & 2 & 10 & 50 \\
\hline & Menari & 3 & 2 & 2 & 3 & 10 \\
\hline & Tidur & 9 & 11 & 3 & 12 & 35 \\
\hline & Traveling & 22 & 31 & 4 & 17 & 74 \\
\hline & Menyanyi & 11 & 12 & 1 & 10 & 34 \\
\hline & Keterampilan & 5 & 5 & 0 & 4 & 14 \\
\hline & Berkebun & 1 & 2 & 1 & 1 & 5 \\
\hline
\end{tabular}


Tabel 6

Hasil Crosstab Responden

Berdasarkan Jenis Kelamin, Jenis Teh, Usia, Daerah Asal Dan Berapa Kali

Dalam Sehari Mengkonsumsi Teh

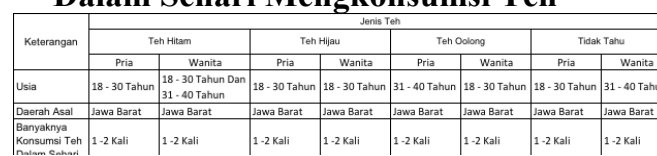

Tabel 7

Responden Berdasarkan Jenis

Kelamin, Jenis Teh Dan Alasan mengkonsumsi Teh

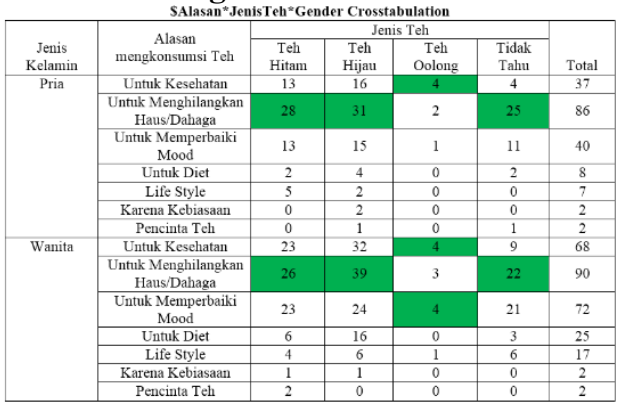

Tabel 8

Responden Berdasarkan Jenis

Kelamin, Jenis Teh Dan Cara

\section{Penyajian Teh}

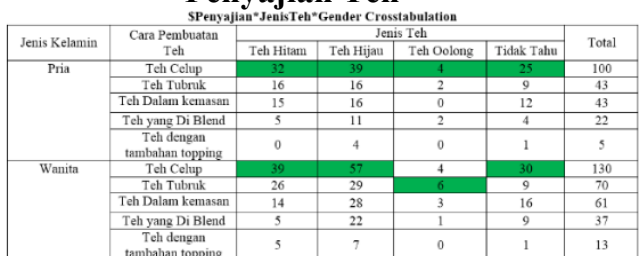

Tabel 9

Responden Berdasarkan Jenis Kelamin, Jenis Teh Dan Merek Teh

\begin{tabular}{|c|c|c|c|c|c|c|}
\hline \multicolumn{7}{|c|}{ SMerek ${ }^{\star} J_{e n i s T e h}{ }^{*}$ Gender Crosstabulation } \\
\hline \multirow{2}{*}{$\begin{array}{c}\text { Jenis } \\
\text { kelamin }\end{array}$} & \multirow[b]{2}{*}{ Merek } & \multicolumn{4}{|c|}{ Jenis Teh } & \multirow[b]{2}{*}{ Total } \\
\hline & & $\begin{array}{c}\text { Teh } \\
\text { Hitam }\end{array}$ & $\begin{array}{c}\text { Teh } \\
\text { Hijau }\end{array}$ & $\begin{array}{c}\text { Teh } \\
\text { Oolong }\end{array}$ & $\begin{array}{l}\text { Tidak } \\
\text { Tahu }\end{array}$ & \\
\hline \multirow[t]{19}{*}{ Pria } & Walini & 6 & 11 & 2 & 2 & 21 \\
\hline & Sosro & 13 & 12 & 0 & 8 & 33 \\
\hline & Sariwangi & 25 & 24 & 2 & 21 & 72 \\
\hline & Tong Tji & 16 & 26 & 2 & 9 & 53 \\
\hline & Upet & 6 & 4 & 1 & 3 & 14 \\
\hline & Lipton & 3 & 3 & 0 & 1 & 7 \\
\hline & Dilmah & 1 & 3 & 0 & 0 & 4 \\
\hline & Frestea & 5 & 4 & 1 & 5 & 15 \\
\hline & Fruitea & 6 & 4 & 0 & 3 & 13 \\
\hline & Poci & 7 & 8 & 1 & 5 & 21 \\
\hline & Teh Kotak & 6 & 10 & 0 & 6 & 22 \\
\hline & Starbuck & 1 & 4 & 0 & 0 & 5 \\
\hline & DhumDhum & 1 & 1 & 0 & 1 & 3 \\
\hline & Chatime & 1 & 3 & 0 & 3 & 7 \\
\hline & Calais & 1 & 2 & 0 & 0 & 3 \\
\hline & KOI & 0 & 1 & 0 & 0 & 1 \\
\hline & Pucuk Harum & 3 & 1 & 0 & 0 & 4 \\
\hline & Nu Green Tea & 1 & 1 & 0 & 0 & 2 \\
\hline & Peko & 0 & 1 & 0 & 0 & 1 \\
\hline \multirow[t]{20}{*}{ Wanita } & Walini & 6 & 10 & 0 & 1 & 17 \\
\hline & Sosro & 12 & 20 & 3 & 8 & 43 \\
\hline & Sariwangi & 30 & 35 & 5 & 22 & 92 \\
\hline & Tong $\mathrm{T}_{\mathrm{ji}}$ & 24 & 43 & 3 & 16 & 86 \\
\hline & Upet & 5 & 8 & 0 & 1 & 14 \\
\hline & Lipton & 5 & 5 & 0 & 2 & 12 \\
\hline & Dilmah & 11 & 8 & 0 & 0 & 19 \\
\hline & Frestea & 6 & 13 & 0 & 3 & 22 \\
\hline & Fruitea & 1 & 6 & 0 & 6 & 13 \\
\hline & Poci & 7 & 9 & 4 & 7 & 27 \\
\hline & Teh Kotak & 12 & 12 & 2 & 12 & 38 \\
\hline & Starbuck & 1 & 3 & 0 & 0 & 4 \\
\hline & DhumDhum & 2 & 2 & 1 & 1 & 6 \\
\hline & Chatime & 0 & 6 & 1 & 2 & 9 \\
\hline & Calais & 1 & 0 & 0 & 0 & 1 \\
\hline & KOI & 0 & 0 & 0 & 1 & 1 \\
\hline & Pucuk Harum & 0 & 0 & 0 & 1 & 1 \\
\hline & Nu Green Tea & 1 & 2 & 0 & 0 & 3 \\
\hline & Kepala Djengot & 1 & 4 & 0 & 0 & 5 \\
\hline & Dua Tang & 1 & 0 & 0 & 0 & 1 \\
\hline
\end{tabular}

Tabel 10

Hasil Crosstab Responden

Berdasarkan Jenis Kelamin, Jenis Teh, Usia, Daerah Asal Dan Alasan Pemilihan Merek

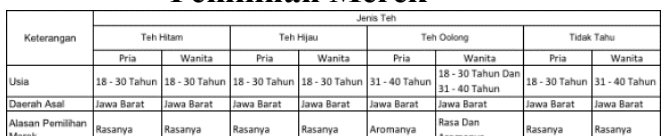

Tabel 11

Hasil Crosstab Responden

Berdasarkan Jenis Kelamin, Jenis Teh, Usia, Daerah Asal Dan Tempat

Membeli Teh

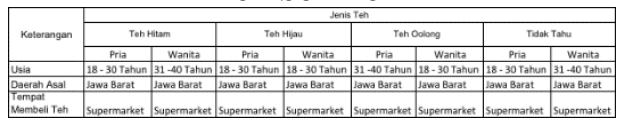


Tabel 12

Hasil Crosstab Responden

Berdasarkan Jenis Kelamin, Jenis Teh, Usia, Daerah Asal Dan Kebiasaan Menikmati Teh Dengan Karakteristik Peminum Teh

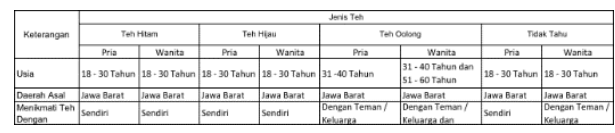

Tabel 14

Karakteristik Peminum Teh Hitam

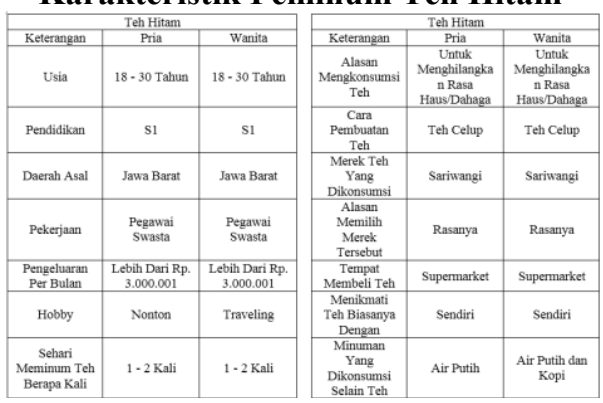

Pada tabel 14 terdapat hasil crosstabulation karakteristik peminum teh hitam.Penikmat teh hitam tersebut adalah pria dan wanita yang berusia $18-30$ tahun. Dalam hal ini konsumen dapat dikategorikan kedalam kelompok usia remaja akhir dan mulai memasuki usia dewasa menurut Depkes tahun 2009 (Yhantiaritra, 2015), usia tersebut apabila dikaitan dengan tingkat pendidikan dan pekerjaan dari responden yaitu tingkat pendidikan S1 dan memiliki pekerjaan sebagai karyawan swasta maka dalam hal ini responden dapat dikategorikan sebagai usia dewasa. Hobby responden yang berjenis kelamin pria adalah nonton dan hobby responden dari peminum teh hitam berjenis kelamin wanita adalah traveling, dari hobby tersebut dapat menjadi bahan masukan untuk pemasar teh dalam menyusun strategi marketing.

Responden peminum teh hitam baik yang berjenis kelamin pria maupun wanita memiliki pengeluaran perbulan lebih dari atau sama dengan Rp. 3.000.001. Menurut

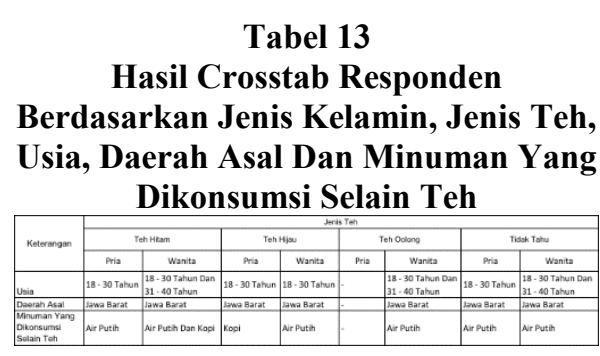

AC Nielsen masuk kedalam kategori kelas A2 yang berarti masuk ke dalam kategori kelas menengah atas (Mulyadi, 2011). Dalam hal ini dapat disimpulkan bahwa rata - rata peminum teh hitam adalah masyarakat kelas menengah atas yang berprofesi sebagai karyawan swasta dan tingkat kesejahteraan yang cukup baik, sehingga daya beli pada masyarakat ini masih terbilang cukup baik, hal ini tergantung pada pihak pemasar bagaimana mengkomunikasikan produk mereka terhadap masyarakat kelas ini. Apabila dilihat dari tingkat pendidikan penikmat teh hitam ini juga memiliki tingkat pendidikan yang cukup tinggi sehingga harus menjadi bahan pertimbangan para pemasar teh dalam mengkomunikasikan produknya.

Responden berasal dari Jawa Barat, masyarakat tanah sunda biasanya menikmati teh tanpa gula (Astarini, 2017). Berbeda kebiasaan dengan yang berasal dari Jawa Tengah yang terkenal dengan teh poci yang memiliki berslogan Nasgitel. Responden memiliki gaya hidup yang praktis, hal tersebut terkait dengan cara pembuatan teh yaitu teh celup. Teh celup adalah salah satu jenis teh yang paling populer di pasaran karena kepraktisan dalam pembuatannya. Merek yang menjadi favorite para responden ini adalah merek Sariwangi. Merek Sariwangi ini memang tidak dapat dilepaskan dari image konsumen teh tentang teh celup, karena Sariwangi adalah salah satu pelopor hadirnya teh celup di Indonesia. Dan merek Sariwangi ini selalu tersedia di 
supermarket, tempat mereka membeli teh dan berbelanja kebutuhan yang lain.

Alasan responden menikmati teh adalah untuk menghilangkan haus dan dahaga dan rata - rata responden menikmati teh $1-2$ kali sehari.Hal ini dapat menjadi perhatian bagi para pemasar teh bahwa para responden menikmati teh sebagai penganti mereka mengkonsumsi air putih, hal ini diperkuat dengan pertanyaan minuman yang dikonsumsi selain teh adalah air putih.Hendaknya para pemasar teh dapat menyediakan produk teh tanpa gula dengan rasa yang ringan.Selain mengkonsumsi teh dan air putih responden berjenis kelamin wanita juga menikmati kopi.Responden berjenis kelamin pria dan wanita lebih suka menikmati teh hitam mereka sendiri, sehingga hal ini dapat menjadi masukan bagi para pemasar teh untuk dapat menyediakan produk teh kemasan sekali minum untuk porsi satu orang.

\section{Tabel 15}

\section{Karakteristik Peminum Teh Hijau}

\begin{tabular}{|c|c|c|c|c|c|}
\hline \multicolumn{3}{|c|}{ Teh Hijau } & \multicolumn{3}{|c|}{ Teh Hijau } \\
\hline Keterangan & Pria & Wanita & Keterangan & Pria & Wanita \\
\hline Usia & 18- 30 Tahun & $18-30$ Tahun & $\begin{array}{c}\text { Alasan } \\
\text { Mengkonsumsi } \\
\text { Teh }\end{array}$ & $\begin{array}{c}\text { Untuk } \\
\text { Menghilangkan } \\
\text { Rasa } \\
\text { Haus Dahaga }\end{array}$ & $\begin{array}{c}\text { Untuk } \\
\text { Menghilangikan } \\
\text { Rasa } \\
\text { Haus Dahaga }\end{array}$ \\
\hline Pendidikan & s1 & si & $\begin{array}{l}\text { Cara } \\
\text { Pembuatan } \\
\text { Teh }\end{array}$ & Teh Celup & Teh Celup \\
\hline Daerah Asal & Jawa Barat & Jawa Barat & $\begin{array}{l}\text { Merek Teh } \\
\text { Yang } \\
\text { Dikonsumsi }\end{array}$ & Toag $\mathrm{TJi}_{\mathrm{j}}$ & Tong $\mathrm{Jji}_{\mathrm{i}}$ \\
\hline Pekerjan & Pelajar Mahasiswa & $\begin{array}{l}\text { Pegawai } \\
\text { Swasta }\end{array}$ & $\begin{array}{l}\text { Alassan } \\
\text { Memilih } \\
\text { Merck } \\
\text { Tersebut }\end{array}$ & Rasanya & Rasanya \\
\hline 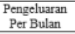 & $\begin{array}{l}\text { Lebih Dari Rp. } \\
3.000 .001\end{array}$ & $\begin{array}{c}\text { Lebih Dari } \\
\text { Rp. 3.000.001 }\end{array}$ & $\begin{array}{l}\text { Tempat } \\
\text { Membeli Teh }\end{array}$ & Supermarket & Supermarket \\
\hline Hobby & Olahraga & Nonton & $\begin{array}{c}\text { Menikmati } \\
\text { Tee Biasanya } \\
\text { Dengan }\end{array}$ & Sendiri & Sendiri \\
\hline $\begin{array}{c}\text { Schari } \\
\text { Meminum } \\
\text { Teh Berapa } \\
\text { Kali } \\
\end{array}$ & 1.2 Kali & 1.2 Kali & $\begin{array}{l}\text { Minumanan } \\
\text { Yang } \\
\text { Dikonsumsi } \\
\text { Selain Teh }\end{array}$ & Kopi & Air Puth \\
\hline
\end{tabular}

Pada tabel 15 terdapat hasil kesimpulan crosstabulation karakteristik peminum teh hijau. Dari 350 responden terdapat 140 responden penikmat teh hijau, jumlah responden teh hijau adalah yang terbanyak dibandingkan dengan jumlah responden penikmat teh yang lain. Hal ini tidak terlepas dari budaya yang sedang tren di Indonesia pada saat sekarang ini yaitu peralihan tentang budaya masyarakat yang lebih hidup sehat dan lifestyle.Banyak masyarakat di daerah perkotaan yang menjaga pola hidup sehat dengan berolah raga dan menjaga asupan gizi mereka.Tetapi karena tingkat kesibukan yang tinggi maka mereka untuk bergaya hidup sehat lebih menjaga asupan gizi dan pola makan (Secawardaya, 2015).Green tea dipercaya mempunyai zat antioksidan tinggi yang mempunyai banyak manfaat adalah salah satu asupan gizi untuk gaya hidup sehat mereka. Adapula penikmat teh hijau ini yang hanya mengikuti lifestyle yang sedang terjadi di Indonesia pada saat sekarang ini, tanpa melihat dari kandungan nilai gizi yang ada di dalam teh hijau mereka mengkonsumsi teh hijau dikarenakan banyak orang mengatakan menyukai teh hijau dan mereka akan dianggap kurang up to date bila tidak menyukai teh hijau (Secawardaya, 2015).

Responden teh hijau berjenis kelamin pria dan wanita berusia $18-30$ tahun, memiliki tingkat pendidikan S1 dan responden pria berprofesi sebagai karyawan swasta sedangkan responden berjenis kelamin wanita berprofesi sebagai pelajar / mahasiswa, maka untuk responden pria dapat dikategorikan ke dalam usia dewasa sedangkan responden wanita dikategorikan ke dalam kelas remaja akhir menurut Depkes 2009 (Yhantiaritra, 2015). Dengan pengeluaran perbulan lebih dari Rp. 3.000.001, menurut AC Nielsen masuk kedalam kategori kelas A2 yang berarti masuk ke dalam kategori kelas menengah atas (Mulyadi, 2011).Peminum teh hijau yang berjenis kelamin pria memiliki hobby berolahraga hal ini sejalan dengan sedang pola hidup sehat yang sedang tren pada masa sekarang dan untuk menjaga penampilan mereka karena salah satu manfaat dari teh hijau adalah untuk menurunkan berat badan.Sedangkan peminum teh hijau berjenis kelamin wanita memiliki hobby nonton.

Responden berasal dari Jawa Barat, cara meminum teh di Jawa Barat adalah diminum tanpa menggunkan gula. Dalam 
hal ini sangat sesuai apabila mereka mengkonsumsi teh hijau karena teh hijau memang kurang pas dengan penyajian menggunakan gula.Rata - rata para responden ini meminum teh sebanyak 1 2 kali dalam sehari. Untuk responden berjenis kelamin pria selain meminum teh hijau mereka juga mengkonsumsi kopi, walaupun sama - sama mengandung kafein tetapi dinilai bahwa teh hijau lebih sehat daripada kopi. Untuk responden berjenis kelamin wanita selain mereka mengkonsumsi teh hijau mereka mengkonsumsi air putih.Para responden baik yeng berjenis kelamin pria maupun wanita mengkonsumsi teh hijau untuk menghilangkan haus/dahaga mereka.

Responden teh hijau ini memiliki gaya hidup yang praktis, hal tersebut terkait dengan cara pembuatan teh yaitu teh celup. Tempat membeli teh hijau para responden adalah di supermarket.Merek teh hijau yang biasa mereka konsumsi adalah merek Tong Tji, merek ini hampir tersedia di seluruh supermarket.Mereka menyukai merek Tong Tji ini dikarenakan rasanya.Para responden ini lebih suka menikmati teh hijau mereka sendiri.Berdasarkan profiling teh hijau yang telah dipaparkan diatas maka diharapkan dapat menjadi bahan masukan untuk pemasar teh hijau yang ada di Indonesia.Yang menarik disini adalah penikmat teh hijau berjenis kelamin wanita memiliki pekerjaan sebagai pelajar/mahasiswa. Para pemasar ini harus jeli untuk mendapatkan informasi tambahan mengapa para pelajar/mahasiswa ini mengemari memilih teh hijau apakah para pelajar ini tertarik untuk mengkonsumsi teh hijau dikarenakan lifestyle, sadar akan gaya hidup sehat, untuk diet atau dikarenakan terbawa oleh selera dari orang tuanya.
Tabel 16

Karakteristik Peminum Teh Oolong

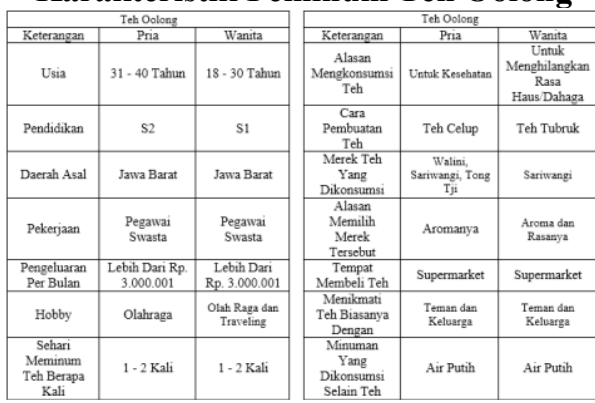

Pada tabel 16 terdapat hasil kesimpulan crosstabulation karakteristik peminum teh oolong.Teh oolong adalah salah satu jenis teh yang kurang dikenal di Indonesia lebih banyak di produksi di Cina dan Taiwan, tetapi pada saat sekarang ini Indonesia sudah mulai memproduksi teh oolong. Penikmat teh oolong berjenis kelamin pria berusia lebih dewasa dibandingkan dengan penikmat teh dari jenis lainnya yaitu 31 - 40 tahun, sedangkan untuk yang berjenis kelamin wanita berusia sama dengan penikmat teh lainnya yaitu 18 - 30 tahun. Tingkat pendidikan penikmat teh oolong ini untuk yang berjenis kelamin pria lebih tinggi dibandingan dengan penikmat jenis teh yang lain yaitu S2 sedangkan untuk yang berjenis kelamin wanita berpendidikan S1. Untuk jenis pekerjaan baik yang berjenis kelamin pria maupun wanita memiliki jenis pekerjaan yang sama yaitu sebagai pegawai swasta. Dari pemaparan diatas maka responden dikategorikan usia dewasa. Pengeluaran perbulan dari para responden lebih dari Rp. 3.000.001, menurut AC Nielsen masuk kedalam kategori kelas A2 yang berarti masuk ke dalam kategori kelas menengah atas (Mulyadi, 2011). Responden teh oolong berasal dari Jawa Barat sangat sesuai dengan selera masyarakat yang berasal dari tanah Sunda ini, hal ini terkait karena teh oolong kurang pas untuk dinikmati 
dengan menambahkan gula kedalam air teh.Peminum teh oolong ini masuk kedalam usia yang lebih matang dibandingkan dengan penikmat teh jenis lainnya, hal ini dikarenakan manfaat yang terdapat di teh oolong diantaranya adalah menjaga kolesterol, menstabilkan gula darah, mencegah tekanan darah tinggi, meningkatkan konsentrasi dan performa, dll. Hal ini diperkuat dengan alasan mereka mengkonsumsi teh yaitu untuk kesehatan dan memperbaiki mood.

Alasan para responden berjenis kelamin pria mengkonsumsi teh oolong adalah untuk kesehatan, hal tersebut sesuai dengan hobby yang digemari adalah olahraga.Sedangkan untuk responden yang berjenis kelamin wanita alasan mengkonsumsi teh oolong adalah untuk kesehatan dan memperbaiki mood. Alasan mengkonsumsi teh oolong pada responden yang berjenis kelamin wanita ini juga sejalan dengan hobby yang digemari oleh meraka yaitu berolah raga untuk alasan kesehatan mereka dan mereka juga memliki hobby traveling untuk membuat mood mereka selalu terjaga dengan baik dengan cara selalu melakukan refresing pada tubuh dan pikiran mereka. Responden peminum teh oolong ini dapat disimpulkan sebagai orang yang sangat menjaga kesehatan mereka, hal ini dapat dilihat dari hobby yang digemari oleh mereka dan minuman yang mereka konsumsi selain teh adalah air putih.

Para responden ini menikmati teh sebanyak 1-2 kali sehari bersama dengan teman atau keluarga. Responden yang berjenis kelamin pria lebih menyukai pembuatan teh dengan teh celup yang terkenal karena kepraktisannya, hal ini dikarenakan mereka tidak perlu repot menyaring ampas dari tehnya. Sedangkan untuk responden yang berjenis kelamin wanita lebih menyukai cara pembuatan teh tubruk hal ini terkait karena rasa dari teh tubruk dipercaya lebih tajam, aroma lebih wangi dan nikmat karena lebih alami apabila dibandingkan dengan teh
celup.Merek yang dikonsumsi responden teh oolong yang berjenis kelamin pria adalah Walini, Sariwangi dan Tong Tji, sedangkan untuk yang berjenis kelamin wanita adalah Sariwangi. Yang menarik disini adalah merek Walini, Sariwangi dan Tong Tji tidak menjual produk yang berjenis teh oolong, hal ini menimbulkan kemungkinan bahwa responden yang mengkonsumsi teh oolong sebenarnya juga tidak mengetahui jenis teh apa yang mereka konsumsi. Hal ini seharusnya membuat para pemasar teh mengali lagi informasi tentang konsumen peminum teh oolong agar kedepannya mereka mengetahui tentang kedudukan produk teh oolong dimata para konsumennya.Responden berjenis kelamin pria memilih merek teh aroma yang terdapat pada saat teh diseduh, sedangkan responden yang berjenis kelamin wanita memilih merek teh yang mereka konsumsi karena rasa dan aroma dari merek tersebut.Mereka biasa membeli teh untuk mereka konsumsi di supermarket.

Tabel 17

Karakteristik Peminum Teh Yang Tidak Mengetahui Jenis Teh Yang Dikonsumsinya

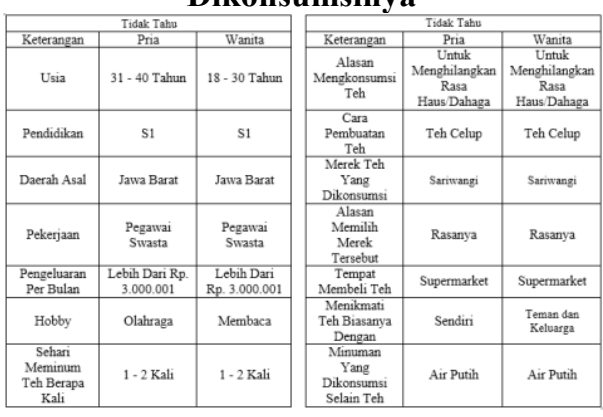

Tabel 17 menampilkan tentang karakteristik peminum teh yang tidak mengetahui tentang jenis teh yang mereka konsumsi.Para penikmat teh ini yang berjenis kelamin pria maupun wanita berusia antara $18-30$ tahun, berpendidikan S1 dan memiliki pekerjaan sebagai pegawai swasta. Maka peminum 
teh ini dikategorikan sebagai usia dewasa. Responden berasal dari Jawa Barat yang memiliki tingkat pengeluaran per bulan sebesar lebih dari Rp. 3.000.001 yang menurut AC Nielsen masuk kedalam kategori kelas A2 dan berarti masuk ke dalam kategori kelas menengah atas (Mulyadi, 2011).

Para penikmat teh ini menyukai gaya hidup yang praktis, hal ini terlihat dari cara mereka menikmati teh yaitu teh celup, yang mereka mengkonsumsi sebanyak 1 -2 kali dalam sehari. Mereka biasa membeli teh yang dikonsumsinya di supermarket. Responden yang tidak mengetahui jenis teh yang mereka konsumsi ini sangat menyukai teh berdasarkan rasanya, mereka tidak terlalu peduli tentang jenis teh apa yang mereka konsumsi apakah itu teh hitam, teh hijau ataupun jenis teh yang lain, yang paling penting bagi mereka adalah rasanya pas untuk ukuran selera mereka masing masing. Hobby responden yang berjenis kelamin pria adalah berolah raga dan yang berjenis kelamin wanita adalah membaca.Para penikmat teh jenis ini hanya menikmati teh untuk menghilangkan haus dan dahaga mereka.

Minuman yang para responden ini konsumsi selain teh adalah air putih.Untuk peminum teh berjenis kelamin pria lebih menyukai menikmati teh mereka sendirian sedangkan untuk responden yang berjenis kelamin wanita lebih menyukai teh bersama dengan teman atau keluarga mereka.Merek teh yang mereka konsumsi baik pria maupun wanita adalah Sariwangi.Untuk yang berjenis kelamin wanita senang menikmati teh saat bersama dengan teman ataupun keluarga dapat dikarenakan sudah sangat setuju dengan slogan "Mari Ngeteh Mari Bicara" yang dikeluarkan oleh Sariwangi, dalam hal ini dapat dikatakan bahwa Sariwangi telah berhasil mempengaruhi para konsumennya dengan slogan yang mereka bangun.Sedangkan yang berjenis kelamin pria lebih senang menikmati teh dengan sendiri, untuk itu perlu kejelian dari Sariwangi dalam mengemas produknya agar pas untuk dinikmati secara personal.

\section{Simpulan dan Saran}

\section{Simpulan}

\section{Tabel 18}

Kesimpulan Hasil Crosstab Dari Keempat Jenis Teh

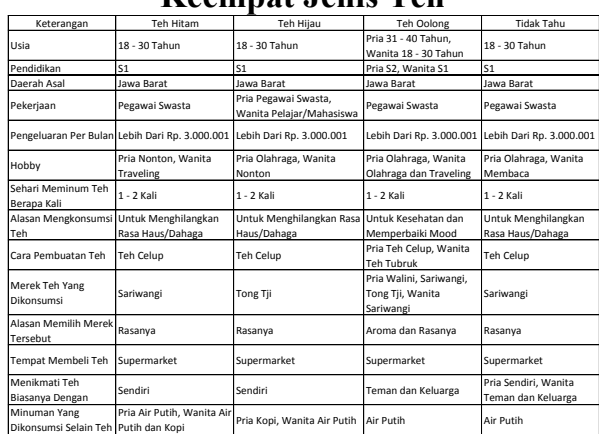

Berdasarkan dari usia, tingkat pendidikan, pekerjaan dan pengeluaran per bulan maka responden dari peminum teh adalah konsumen dengan kategori menengah keatas sehingga strategi pemasaran yang dapat dilakukan oleh pemasar teh adalah memberikan edukasi tentang teh terhadap konsumen serta memberikan pengalaman berupa sample agar para meminum teh mengetahui rasa teh yang akan dijual oleh pemasar. Edukasi yang diberikan dapat berupa apa manfaat yang didapatkan apabila rutin dalam mengkonsumsi produk teh, bagaimana cara menyeduh teh yang benar, bagaimana cara minum teh yang benar, dll. Hendaknya para pemasar teh juga mempertimbangkan produk yang akan dijual terhadap segmentasi konsumen kelas menengah atas ini.

Berdasarkan daerah asal, dalam penelitian ini adalah Jawa Barat, banyaknya minum teh dalam sehari adalah $1-2$ kali serta minuman yang dikonsumsi selain teh paling banyak menjawab air putih maka dapat disimpulkan bahwa para peminum teh ini menginginkan adanya 
pemasar teh yang membuat teh dalam kemasan dengan rasa teh yang tawar tetapi tidak terlalu pahit, serta menyegarkan.Dalam hal ini karena para peminum teh ini sudah menganggap bahwa teh adalah minuman yang dapat dikonsumsi sehari-hari selain air putih, maka rasa teh harusnya bersifat ringan dan tidak mengandung bahan pengawet makanan yang berbahaya bagi tubuh manusia.Rasa teh yang diharapkan bersifat ringan dan menyegarkan karena berdasarkan kuesioner banyak dari peminum teh yang mengkonsumsi teh hanya untuk menghilangkan haus dan dahaga mereka.

Para responden peminum teh ini juga merupakan orang - orang yang praktis terlihat bahwa sebagian besar peminum teh ini sangat mengemari cara meminum teh dengan teh celup. Dan mereka lebih menyukai membeli teh di supermarket, dalam hal tempat memang supermarket dapat dikatakan lebih nyaman daripada warung ataupun pasar tradisional.Mereka lebih menyukai membeli teh di supermarket dapat juga dikarenakan mayoritas dari peminum teh ini adalah memiliki pekerjaan sebagai karyawan swasta, sehingga mereka menganggap bahwa jam operasional supermarket lebih fleksibel dengan waktu kerja mereka, mereka dapat berbelanja dan membeli teh pada saat jam kerja mereka telah usai.

Usia dan tingkat pendidikan responden untuk peminum teh oolong berjenis kelamin pria lebih dewasa dibandingkan dengan penikmat jenis teh yang lainnya. Hal ini terkait dengan manfaat yang terkandung pada teh oolong.Teh oolong dipercaya memiliki manfaat.

\section{Saran}

\section{Bagi Pemasar Teh}

a. Membuat inovasi pada produk teh dalam kemasan, baik itu kemasan gelas, kotak ataupun botol untuk ukuran personal yaitu $250 \mathrm{ml}-600 \mathrm{ml}$ dengan aroma khas teh, tawar tetapi tidak terlalu pekat, sehingga rasa teh lebih ringan dan tidak terlalu pahit. Dan meminimalisir penggunaan pengawet sehingga teh lebih sehat.

b. Membuat edukasi baik berupa iklan atau penyuluhan tentang cara menyeduh teh yang baik dan sehat. Hal ini dikarenakan para penikmat pada jaman sekarang ini lebih menyukai teh celup. Kantung dari teh celup dianggap berbahaya apabila direndam terlalu lama pada minuman teh karena banyak ditemui zat klorin, jadi edukasi kepada masyarakat sangat diperlukan. Dalam hal ini pemasar merek Sariwangi diharapkan dapat lebih aktif mengingat Sariwangi merupakan pelopor teh celup di Indonesia.

c. Menjadi sponsor dalam kegiatan atau event olahraga yang diselengarakan baik itu dalam tingkat daerah, nasional ataupun internasional dikarenakan banyaknya penikmat teh yang memiliki hobby berolahraga.

d. Untuk produk teh yang mempunyai responden dengan hobby nonton maka para pemasar teh ini dapat bekerjasama dengan bioskop untuk mempromosikan produk mereka. Promosi ini dapat berupa sampel teh gratis atau berupa potongan harga untuk pembelian minuman teh dengan syarat dan ketentuan yang berlaku, yang telah disepakati dengan pihak pengelola bioskop.

e. Untuk para pemasar teh yang mempunyai responden dengan hobbytraveling, maka para pemasar teh ini dapat bekerjasama dengan agen - agen travel untuk mempromosikan produk mereka. Promosi ini dapat berupa pemberian minuman gratis kepada konsumen ketika mereka membeli paket tour atau tiket pada agen travel tersebut atau dapat juga memberikan potongan harga kepada agen travel tersebut untuk menjamu para konsumen mereka dengan 
minuman produk pemasar teh. Apabila pemasar teh ini mempunyai kebun teh sendiri maka para pemasar teh ini dapat menjual paket tour ke kebun teh kepada para konsumennya, mungkin akan lebih menarik apabila para konsumen ini dapat melihat dan ikut merasakan langsung bagaimana teh ini diproduksi.

f. Membuat tempat minum teh yang sekelas Starbuck sehingga teh dapat menjadi setara dengan produk kopi. Para karyawan di tempat minum teh tersebut harus dibekali dengan pengetahuan tentang produk teh, sehingga apabila para pembeli yang datang ke sana dapat memperoleh pengetahuan tentang teh. Dengan banyaknya tempat minum teh berkelas diharapkan akan menghilangkan image bahwa teh hanya sekedar minuman gratis yang disediakan di warung.

g. Menjual teh dengan kualitas premium di Indonesia. Teh premium diproduksi dari daun teh yang paling bagus, hanya bagian pucuk daun teh yang digunakan. Teh kualitas premium dapat dilihat dari bentuk daun yang utuh, aroma teh yang semerbak harum meskipun sudah diseduh beberapa kali. Melihat dari tingkat pengeluaran perbulan dari para peminum teh ini maka seharusnya teh premium sangat mungkin untuk di pasarkan di Indonesia.

\section{Bagi pemerintah}

Selalu mendukung dan memfasilitasi acara - acara yang bertemakan tentang teh, salah satu acara tentang teh yang ada di kota Bandung adalah Bandung Tea Festival. Dalam acara Bandung Tea Festival tidak hanya terdapat teh kering saja tetapi ada banyak jenis makanan dan minuman yang berasal dari produk teh yang dapat dinikmati oleh para penikmat teh.

\section{Bagi peneliti selanjutnya}

Melakukan penelitian tentang teh ini lebih lanjut dengan range umur yang lebih kecil, sehingga karakteristik peminum teh dapat menjadi lebih terlihat. Serta dapat menambahkan faktor - faktor lainnya untuk menentukan karakteristik konsumen peminum teh yang belum terdapat pada penelitian ini.

\section{Daftar Pustaka}

Aaker, D., Kumar, V., \& Day, G. (2001). Marketing Research. Wiley.

Alamsyah, F., Oktini, D. R., \& Muchlis, R. D. (2005, Juli). Pengaruh Karakteristik Konsumen Dan Penjual Serta Unsur Produk Terhadap Tingkat Konsumsi Teh (Kasus pada Konsumen Rumah Tangga di Daerah Pemasaran Kota Bandung). Jurnal Sosial Dan Pembangunan, 311-341.

Astarini, D. (2017, September 24). Unik, Budaya Minum Teh Di Berbagai Daerah Di Indonesia. Retrieved Juni 24, 2018, from www.merahputih.com: https://merahputih.com/post/read/unikbudaya-minum-teh-di-berbagaidaerah-di-indonesia

Bisnis. (2013, 7 1). Permintaan Teh Hijau Dunia Bertumbuh Lebih Tinggi. (F. Maskur, Editor) Retrieved 11 16, 2017, from www.bisnis.com: http://industri.bisnis.com/read/201307 01/99/148152/permintaan-teh-hijaudunia-bertumbuh-lebih-tinggi

Bogdan, R., \& Taylor, S. (1992). Introduction to Qualitative Research Methotds : A Phenomenological Approach in the Social Sciences. (J. W. Arief Furchan, Trans.) Surabaya: Usaha Nasional.

BPS. (2017). Jumlah Penduduk Menurut Kelompok Umur dan Jenis Kelamin di Kota Bandung 2016. Retrieved Juli 24, 2018 , from https://bandungkota.bps.go.id: https://bandungkota.bps.go.id/statictabl e/2017/08/29/104/jumlah-penduduk- 
menurut-kelompok-umur-dan-jeniskelamin-di-kota-bandung-2016-.html

Dehotman, F. (2018, 1 26). Empat Kue Tradisional di Bandung yang Layak Dicoba, dari yang Original sampai Modifikasi. Retrieved 3 18, 2018, from http://www.tribunnews.com: http://www.tribunnews.com/travel/201 8/01/26/empat-kue-tradisional-dibandung-yang-layak-dicoba-dari-yangoriginal-sampai-modifikasi

Destriyana. (2015, 9 28). Ini \& Kasiat Teh Oolong Yang Jarang Diketahui. Retrieved 6 1, 2018, from www.merdeka.com:

https://www.merdeka.com/sehat/ini-7khasiat-teh-oolong-yang-jarangdiketahui.html

Dokter Internet Marketing. (2017, 1 15). Retrieved 11 24, 2017, from www.dokter-im.com: https://dokter$\mathrm{im} . \mathrm{com} / \mathrm{blog} /$ pengertian-definisistrategi-pemasaran-marketing/

Keningar, I. (2015, 05 04). Retrieved 11 17, 2017, from www.liputan6.com: http://lifestyle.liputan6.com/read/2223 380/potensi-teh-hijau-di-indonesia

Kotler, P., \& Armstrong, G. (2012). Principles of Marketing (14 ed.). Global Edition.

Kotler, P., \& Keller, K. L. (2009). Marketing Management (13 ed.). New Jersey: Pearson Prentice Hall.

Lamb, H. (2001). Pemasaran (Terjemahan). Jakarta: Salemba Empat.

Laseduw, J. (2014, Januari 23). Manfaat Dari Antioksidan Yang Terkandung Di Dalam Teh. Retrieved Maret 13, 2018, from http://necturajuice.com/: http://necturajuice.com/manfaat-dariantioksidan-yang-terkandung-didalam-teh/

Marwan, A. (1990). Marketing. Yogyakarta: BPFE Universitas Gadjah Mada.

Meriza, F., Lestari, D. A., \& Soelaiman, A. (2016, Januari). Sikap Dan Kepuasan Rumah Tangga Konsumen
Teh Celup Sariwangi Dan Sosro Di Bandar Lampung. Jurnal Ilmu-ilmu Agribisnis, 67-75.

Muhaimin, A. (2010, April). Perilaku Konsumen Dalam Pembelian Teh Rosella Merah Di Kota Malang. Jurnal AGRITEK, 176-184.

Mulyadi, I. (2011, Juni 28). Melakukan Segmentasi Dengan Demografi. Retrieved Juni 21， 2018， from www.marketing.co.id:

https://marketing.co.id/demografisegmen-menengah-atas/

Novalius, F. (2016, 11 21). economy.okezone.com. Retrieved 01 14, 2018, from www.okezone.com: https://economy.okezone.com/read/20 16/11/21/320/1547087/konsumsi-tehindonesia-ditargetkan-naik-jadi-500gram-kapita

Pasigai, M. (2009, April). Pentingnya Konsep Dan Strategi Pemasaran Dalam Menghadapi Persaingan Bisnis. Jurnal Ilmu Ekonomi Studi Pembangunan, 51-56.

Putri, D. A., Maria, S., Sabrina, Y., Fawwas, M., \& Ihya, I. (2014, 9 14). Kaitan Strategi Pemasaran. Retrieved 12 10, 2017, from http://puputdaep.blogspot.co.id:

http://puputdaep.blogspot.co.id/2014/0 9/kaitan-strategi-pemasarandengan.html

Putri, W. D., Stevani, \& Eprillison, V. (2016). Pengaruh Persepsi Konsumen, Motivasi Konsumen Dan Sikap Konsumen Terhadap Keputusan Pembelian Teh Dalam Kemasan Merek Teh Botol Sosro Di Kota Padang.

Reyner, B. (2017). Profilling ECommerce. Bandung, Indonesia: Universitas Katolik Parahyangan.

Rizan, M., Saidani, B., \& Sari, Y. (2012). Pengaruh Brand Image Dan Brand Trust Terhadap Brand Loyalty Teh Botol Sosro. Jurnal Riset Manajemen Sains Indonesi, 1-17. 
Santos, M. C., Veiga, C., \& Águas, P. (2016). Tourism services: facing the challenge of new tourist pro les. Worldwide Hospitality and Tourism Themes, 8, 654-669.

Business Administration.

Schiffman, L., \& Kanuk, L. L. (2010). Consumer behavior (10 ed.). English: Upper Saddle River, N.J. : Prentice Hall, c2010.

Secawardaya, T. (2015, 4 7). Fenomena Green Tea. Retrieved 6 1, 2018, from https://timothysecawardaya.wordpress. com/2015/04/07/fenomena-teh-hijauby-timothy-secawardaya/

Sekretariat Jenderal Kementerian Pertanian. (2016). Outlook Teh. Jakarta: Pusat Data dan Sistem Informasi Pertanian.

Setiawan, D. (2016, 9 1). (Iswidodo, Ed.) Retrieved 10 18，2017， from www.jateng.tribunnews.com: http://jateng.tribunnews.com/2016/09/ 01/data-terkini-jumlah-pendudukindonesia-2579-juta-yang-wajib-ktp1825-juta

Sheth, J. N., Newman, B. I., \& Mittal, B. (1998). Customer Behavior: Consumer Behavior \& Beyond.

Soekotjo, I. (2015). Ragam Tradisi Minum Teh Di Dunia. Retrieved Maret 13, 2018, from www.apakabardunia.com: http://www.apakabardunia.com/2015/1 1/ragam-tradisi-minum-teh-didunia.html

Solomon, M. R. (2011). Consumer Behavior; Buying Having, and Being (7 ed.). New Jersey: Pearson Prentice Hall.

Sugiyono. (2017). Metode Penelitian Kuantitatif, Kualitatif dan $R \& D$. Bandung: Alfabeta.

Sutomo, H., Sukanata, I. K., \& Martani, K. R. (2015, April). Perilaku Konsumen Terhadap Pembelian Pepaya California. Jurnal Agrijati, 28, 114-144.

Syarif, D. R. (2014). Strategi Pengembangan Agribisnis Teh dalam
Rangka Peningkatan Daya Saing Ekspor Komoditas Teh Indonesia di Pasar Dunia. Jurnal Teh.

Tiara, I. (2015, Juni 24). 10 Karakteristik Konsumen Indonesia. Retrieved Maret 18, 2018, from www.kompasiana.com: https:/www.kompasiana.com/inatiara/ 10-karakteristik-konsumen-indonesiabeliindonesia_551889f4a33311ae07b6656 c

Tjiptono, F. (2002). Strategi Pemasaran. Yogyakarta: Andy.

Towaha, J., \& ET, B. (2012, November 29). Mengenal 4 Macam Jenis Teh. Retrieved Juli 24, 2018, from http://balittri.litbang.pertanian.go.id: http://balittri.litbang.pertanian.go.id/in dex.php/home/49-infotekno/159mengenal-4-macam-jenisteh? format $=$ pdf

Tutut, P. (2017, Agustus 2017). Sejarah Awal Masuknya Teh ke Indonesia. Retrieved Maret 12, 2018, from www.reddink.com:

http://www.reddink.com/pengetahuan/ sejarah-awal-masuknya-teh-keindonesia/

Whalley, A. (2010). Strategic Marketing. Ventus Publishing ApS.

Wu, J.-T. B., Lin, I. J., \& Yang, M. H. (2009). The Impact Of A Customer Profile And Customer Participation On Customer Relationship Management Performance. International Journal of Electronic Business Management, 5769.

Yhantiaritra. (2015, Juni 3). Kategori Umur Menurut DEPKES. Retrieved Juli 29, 2018, from https://yhantiaritra.wordpress.com: https://yhantiaritra.wordpress.com/201 5/06/03/kategori-umur-menurutdepkes/

Yunita, E., Sudarma, I. M., \& Dewi, I. A. (2017, Oktober). Faktor Penentu Keputusan Konsumen dalam Mengkonsumsi Teh Celup Sariwangi (Studi Kasus pada Konsumen Tiara 
Jurnal Akuntansi Maranathan Volume 11 Nomor 1, Mei 2019 :77 - 97

Dewata Group di Kota Denpasar). EJournal Agribisnis dan Agrowisata (Journal of Agribusiness and Agritourism), 543-552. 